\title{
A TUTELA INIBITÓRIA E DE REMOÇÃo DE ILÍCITO PARA A PRESERVAÇÃO DA ORDEM URBANÍSTICA
}

\section{ARTIGO ORIGINAL}

OLIVEIRA, Ilka Suemi Nozawa de ${ }^{1}$

OLIVEIRA, Illka Suemi Nozawa de. A tutela inibitória e de remoção de ilícito para a preservação da ordem urbanística. Revista Científica Multidisciplinar Núcleo do Conhecimento. Ano 05, Ed. 07, Vol. 02, pp. 05-27. Julho de 2020. ISSN: 2448-0959, Link de acesso: https://www.nucleodoconhecimento.com.br/lei/ordem-urbanistica

\section{RESUMO}

O licenciamento edilício é o ato administrativo que tem por finalidade autorizar o interessado a construir uma edificação em conformidade com as normas de direito público que disciplinam o direito de construir, observadas as restrições urbanísticas. Nas hipóteses em que há elementos que demonstram indícios de violação ao direito, a tutela inibitória e a sua concessão em caráter provisório antecipado constitui medida processual adequada para a finalidade de preservação da ordem urbanística, independentemente da demonstração de possível ocorrência de dano. Caso o ilícito já tenha ocorrido, a tutela de remoção de ilícito pode ser utilizada. Nos termos dos arts. 497 e 536 do Código de Processo Civil, o juiz pode determinar de ofício ou a requerimento da parte, as medidas executivas necessárias para assegurar a tutela do direito material, além da possibilidade de imposição de medidas coercitivas típicas e atípicas conforme estabelece o art. 139, IV do Código de Processo Civil. O § $3^{\circ}$ do art. 300 do Código de Processo Civil que prescreve limitação para a concessão da tutela antecipada quando houver perigo de irreversibilidade dos efeitos da decisão, à luz do caso concreto, deve ser ponderado para considerar o provável direito do autor que

\footnotetext{
${ }_{1}^{1}$ Advogada, mestranda em Direito Urbanístico pela PUC/SP, cursou como aluna especial o mestrado em arquitetura e urbanismo na Universidade de Brasília - UnB, nas disciplinas Espaço e Organização Social e Espaço e Meio Ambiente (2016).
} 
objetiva tutela para inibição ou remoção de um ilícito em detrimento do possível dano irreversível.

Palavras-chave: licenciamento edilício, direito urbanístico, tutela inibitória e de remoção de ilícito, tutela provisória de natureza antecipada.

\section{INTRODUÇÃO}

O direito urbanístico constitui um importante ramo do direito que merece ser aprofundado diante de uma realidade que envolve ordenar o interesse da coletividade no meio urbano, pois é "produto de transformações sociais que vêm ocorrendo nos últimos tempos" (SILVA, 2015, p. 36).

No Brasil, o processo de ocupação do solo foi fortemente influenciado por núcleos de aglomerações que tinham atividades relacionadas ao período colonial, como produção de café, extração de minério, cana-de-açúcar, dentre outras atividades. Inicialmente a ocupação se desenvolveu ao longo da costa litorânea, posteriormente em Minas Gerais, Goiás e Brasília com a criação da Capital e a forte concentração pelo processo de industrialização fixada no triângulo São Paulo, Rio de Janeiro e Minas Gerais (SILVA, 2015).

O direito urbanístico como ciência é o "ramo do direito público que tem por objeto expor, interpretar e sistematizar as normas e princípios reguladores da atividade urbanística" (SILVA, 2015, p. 38).

As normas de direito urbanístico objetivam assegurar os interesses da comunidade, disciplinam o uso, a ocupação e o parcelamento do solo urbano, além de disciplinar o sistema viário e, de forma mais ampla, regular o planejamento urbano impondo limitações para o exercício do direito de propriedade e de construir, além de instituir instrumentos de intervenção urbana (SAULE, 1997).

A política urbana brasileira norteia-se por princípios constitucionais, especialmente pelo disposto nos artigos 182 e 183 da Constituição Federal. 
Além da previsão constitucional, a lei o 10.257/2001, denominada Estatuto da Cidade, introduziu diretrizes básicas que objetivam a ordenação do pleno desenvolvimento das funções sociais da cidade e da propriedade urbana.

No âmbito Municipal e do Distrito Federal, o Plano Diretor é considerado o instrumento básico para o desenvolvimento e expansão urbana.

Os Municípios e o Distrito Federal devem fixar diretrizes com o objetivo de ordenar o pleno desenvolvimento das funções sociais da cidade e da propriedade urbana. $O$ planejamento municipal e distrital deverá ser concretizado por meio do Plano Diretor, assim como por meio de norma para disciplinar o parcelamento, o uso e ocupação do solo, dentre outros instrumentos gerais que estão estabelecidos no artigo $4^{0}$ do Estatuto da Cidade.

Compete ainda aos Municípios e ao Distrito Federal, o estabelecimento de normas edilícias, seguindo ao que dispõe o artigo $2^{\circ}$, incisos VI e XV do Estatuto da Cidade.

As regras de uso e ocupação do solo e as normas edilícias definem os critérios que devem ser cumpridos para o atendimento da função social da propriedade urbana.

O licenciamento edilício é um instrumento de controle urbanístico, que tem por objetivo atestar a observância das normas pelos seus destinatários, sendo a competência de o Poder Público realizar o controle (SILVA, 2015).

$\mathrm{Na}$ ordenação da ocupação do solo, o licenciamento edilício tem como finalidade atestar a conformidade das normas de direito público que disciplinam o direito de construir e as restrições urbanísticas, sem prejuízo da incidência das normas de direito privado, denominados direito de vizinhança, à luz do que prescreve o art. 1.299 do Código Civil (SILVA, 2015).

Em algumas situações fáticas, construções começam a ser erigidas antes mesmo de a Administração Pública emitir atos procedimentais preparatórios à expedição do ato administrativo de licenciamento edilício. Situações como a exemplificada configuram 
construções irregulares que devem ser impedidas por meio da adoção de ações judiciais como pedidos de tutela inibitória ou de remoção de ilícito.

A observância das normas urbanísticas que proclamam regras que objetivam proteger o interesse coletivo é um dever que se impõe. Na hipótese de ameaça de violação às normas urbanísticas, cabe ao Poder Judiciário, quando provocado, diante da análise do caso concreto, conceder medidas que tenham o alcance necessário a fim de proteger o direito material e que não resulte apenas e tão somente na perspectiva de ressarcimento de eventual dano.

Como exemplo, nas hipóteses de construções não licenciadas pelo Poder Público, os empreendimentos, especialmente de médio e grande porte, quando edificados, em determinadas situações podem representar dano alto grau de dificuldade e impactos ambientais negativos em razão dos resíduos produzidos pela construção civil e demolição da edificação.

Assim, considerando a importância do tema, o objetivo deste estudo é analisar a tutela inibitória e de remoção de ilícito assim como a possibilidade de sua concessão em caráter provisório antecipado como medida adequada para preservação da ordem urbanística.

Dessa forma, nos tópicos a seguir serão abordados os temas: (i) do licenciamento edilício à luz do Estatuto da Cidade e do Plano Diretor; (ii) da tutela inibitória e de remoção de ilícito; (iii) da tutela inibitória em caráter antecipado e da efetividade do processo; (iv) da tutela inibitória negativa e da tutela inibitória positiva; (v) da tutela inibitória ou de remoção de ilícito e as medidas coercitivas típicas e atípicas; e, (vi) conclusão.

\section{DO LICENCIAMENTO EDILÍCIO À LUZ DO ESTATUTO DA CIDADE E DO PLANO DIRETOR}

As normas urbanísticas visam disciplinar a ordenação do território e para essa afirmação, José Afonso da Silva, ensina que o direito urbanístico é um ramo do direito 
que congrega "um conjunto de normas jurídicas reguladoras da atividade do Poder Público destinada a ordenar os espaços habitáveis - o que equivale dizer: conjunto de normas jurídicas reguladoras da atividade urbanística" (SILVA, 2012, p. 37).

A Constituição Federal de 1988 atribuiu competência concorrente à União, aos Estados e ao Distrito Federal para legislar sobre matéria de direito urbanístico, restringindo à União, no âmbito da legislação concorrente, editar normas gerais e aos Estados e ao Distrito Federal editar normas específicas nos termos do $\S^{\circ}{ }^{\circ}$ do art. 24.

Na hipótese de a União editar normas gerais, o §2ํำ do art. 24 da Constituição Federal estabelece que os Estados e o Distrito Federal devem legislar por competência suplementar.

Além disso, compete aos Municípios e ao Distrito Federal legislar sobre assuntos de interesse local, nos termos do art. 30, I da Constituição Federal, assim como editar o Plano Diretor, nos termos do art. 182, $\S 1^{\circ}$ da Constituição Federal.

Ao regulamentar os arts. 182 e 183 da Constituição Federal de 1988, o Estatuto da Cidade (Lei № 10.257/2001) instituiu no art. 2o diretrizes básicas que objetivam ordenar o pleno desenvolvimento das funções sociais da cidade e da propriedade urbana, sendo de competência municipal e do Distrito Federal, como acima citado, legislar sobre assuntos de interesse local. Saule (1997) ensina que

O direito de propriedade é garantido desde que atenda a sua função social, de acordo com o artigo 5o incisos XXII e XXIII. A propriedade privada como um dos princípios gerais da ordem econômica, para atender a sua função social deve estar vinculada as finalidades de ordem econômica de assegurar a todos a existência digna, conforme os ditames da justiça social. A função social da propriedade em consonância com os demais princípios constitucionais, é o mandamento principal do regime da propriedade urbana que deve ser disciplinado pelo direito público (SAULE, 1997, p. 54 e 55).

As normas que tratam de planejamento e controle do uso, do parcelamento e da ocupação do solo urbanos são consideradas de interesse local e, portanto, de competência privativa dos Municípios e do Distrito Federal com base no inciso VIII do art. 30 da Constituição Federal. 
No plano constitucional, dentre os direitos e garantias fundamentais, no capítulo I que trata dos direitos e deveres individuais e coletivos, consta o direito de propriedade assim como a determinação que a propriedade deverá atender a sua função social (art. 5ㅇ, XXII e XXIII).

O direito de propriedade deve relacionar-se com outros princípios e regras constitucionais e infraconstitucionais, especialmente em relação ao planejamento e ordenamento territorial. Por esta razão, o direito de construir é assim, condicionado às prescrições administrativas (MALUF, 2007).

O direito de construir está previsto no art. 1.299 do Código Civil, que garante, ao proprietário, o direito de construir, devendo observar, entretanto, o direito dos vizinhos e os regulamentos administrativos. Segundo Figueiredo (1980):

Verificamos ser a licença para construir um ato administrativo constitutivo-formal, possibilitando àquele em favor de quem é expedida, o direito de levar a cabo a construção, nos termos em que foi deferida: isto é, de acordo com o projeto aprovado e no prazo estipulado (FIGUEIREDO, 1980, p. 58)

As licenças urbanísticas, especialmente as edilícias, apresentam-se como ato administrativo de competência vinculada em que o interessado é obrigado a requerêlas e, se preenchidos os requisitos legais, não podem ser negadas pela Administração Pública. As modalidades mais comuns são as licenças para edificar, reformar, reconstrução ou demolições, além das licenças para atividades comerciais, industriais, institucionais ou de prestação de serviços (SILVA, 2012).

A licença para edificar "não constitui nem uma autorização, nem uma concessão, mas um ato de controle de um direito predeterminado quando ao seu conteúdo" (SILVA, 2012, p. 439).

O procedimento administrativo para o licenciamento de edificação deve seguir as diretrizes fixadas por normas municipais que, e, se atendidos os requisitos, a Administração Pública expede o Alvará de Execução ou Alvará de Construção. Ao término da construção, cumpridas as exigências edilícias e urbanísticas, a 
Administração Pública atesta o seu cumprimento por meio do Auto de Conclusão ou Carta de Habite-se (SILVA, 2012).

Não havendo a autorização da Administração Pública para edificar ou sem obter o atestado de conclusão, a eventual ocupação será irregular e estará sujeita às sanções previstas em lei em razão da violação das normas edilícias e urbanísticas.

Os instrumentos de controle urbanístico visam proteger a legalidade urbanística e, na maioria dos casos, exigem uma atuação de controle repressivo que pode ser de natureza pecuniária (multa), interdições de atividade (visando corrigir, por exemplo, normas de uso) ou embargo de obra ou demolição compulsória (SILVA, 2012).

Dentre as modalidades de controle repressivo indicadas, o embargo de obra destinase a determinar a paralisação de obra por infração às normas específicas municipais ou na hipótese de ausência de licença.

A demolição compulsória visa corrigir a infração pelo desfazimento da obra nas hipóteses em que não se mostra possível a correção por outro meio, como na hipótese de obra clandestina e obra em áreas públicas. Nas lições de Silva (2012),

Entende-se que, tratando-se de obra licenciada, a ordem de demolição não pode ser expedida sumariamente, pois primeiramente há que se estabelecer um processo, ouvido o interessado, no qual se desfaça a licença, por anulação, revogação ou cassação, conforme o caso; só depois disso é que deve, se o interessado, por si, não providenciar a demolição, esta se deverá realizar compulsoriamente, inclusive com a força policial. Se a obra é clandestina, a ordem de demolição pode efetivar-se sumariamente (SILVA, 2012, p. 453).

Pode ocorrer que a própria Administração descumpra os preceitos legais, "quer outorgando direitos não permitidos pelo ordenamento, quer furtando-se ao dever de fiscalizar as normas deste ordenamento, ou, então, denegando ao administrado a prestação devida" (FIGUEIREDO, 1980, p. 93).

A afirmação acima apenas reforça que a legislação urbanística deve ser atendida por todos, quer pela Administração quer pelo administrado. 
Nas hipóteses de violação às normas edilícias e urbanísticas, é possível que ações judiciais sejam propostas pela própria Administração Pública, Ministério Público ou pelo administrado ou por particulares no âmbito do direito de vizinhança.

A tutela inibitória e de remoção de ilícito se revela como uma medida adequada para a preservação da ordem urbanística, conforme será apresentado nos tópicos seguintes.

\section{DA TUTELA INIBITÓRIA E DA TUTELA DE REMOÇÃO DE ILÍCITO}

O artigo 497 Código de Processo Civil de 2015 prescreve que:

Art. 497. Na ação que tenha por objeto a prestação de fazer ou de não fazer, o juiz, se procedente o pedido, concederá a tutela específica ou determinará providências que assegurem a obtenção de tutela pelo resultado prático equivalente.

Parágrafo único. Para a concessão da tutela específica destinada a inibir a prática, a reiteração ou a continuação de um ilícito, ou a sua remoção, é irrelevante a demonstração da ocorrência de dano ou da existência de culpa ou dolo.

O referido dispositivo trata da tutela inibitória e da tutela de remoção de ilícito por meio de ação de conhecimento, de natureza preventiva a fim de impedir a prática, a repetição ou a continuação de ilícito, assim como para possibilitar a remoção dos efeitos de uma conduta ilícita já praticada. Marinoni (2004) ensina que

A ação inibitória se funda no próprio direito material. Se várias situações de direito substancial, diante de sua natureza, são absolutamente invioláveis, é evidente a necessidade de admitir uma ação de conhecimento preventiva. Do contrário, as normas que proclamam direitos, ou objetivam proteger bens fundamentais, não teriam qualquer significação prática, pois poderiam ser violadas a qualquer momento, restando somente o ressarcimento do dano (MARINONI, 2004, p. 253).

A tutela inibitória tem fundamento na própria Constituição Federal de 1988, em que consta como garantia que "nenhuma lei excluirá da apreciação do Poder Judiciário lesão ou ameaça a direito" (art. $5^{\circ}, \mathrm{XXXV}$ ). A previsão constitucional assegurou, 
portanto, que a tutela deve estar apta a coibir a prática, repetição ou a continuação de ilícito.

O mesmo entendimento se aplica para a tutela de remoção de ilícito, com a diferença que a esta será adequada para as hipóteses em que já houve a prática da ação ilícita, bem como há necessidade de afastar ou inibir os efeitos que tendem a se propagar.

Note-se que em ambas as tutelas inibitórias ou de remoção de ilícito não é necessária a demonstração da ocorrência de dano ou da existência de culpa ou dolo, pois o que se objetiva é inibir a prática de ação ilícita ou removê-la, a fim de assegurar o direito material.

A prática contrária ao que o direito estabelece, independentemente da ocorrência de dano ou da existência de culpa ou dolo, já é suficiente para que sejam garantidas as tutelas específicas inibitórias ou de remoção de ilícito.

Nos termos do parágrafo único do art. 497 do Código de Processo Civil, a ação inibitória pode atuar para prevenir a prática de um ilícito, obstar a repetição ou a continuação de ilícito.

A tutela inibitória para prevenir a prática de ilícito exige a demonstração da probabilidade de um ilícito acontecer, cuja tarefa probatória, apesar de difícil, pode ser demonstrada por meio de fatos que constituam indícios de que o ilícito será praticado (MARINONI, 2004).

A análise de forma distinta entre a conduta que constitui o ato ilícito e os efeitos concretos desta conduta que podem acarretar o dano é de fundamental importância, para que sejam direcionadas medidas processuais adequadas contra a probabilidade do ilícito ou a remoção dele, independentemente da potencialidade de efeitos danosos possíveis ou prováveis.

Nas lições de Marinoni, "A necessidade de ação inibitória não tem nada a ver com a questão da prova. A dificuldade da prova não pode constituir obstáculo à ação inibitória, seja ela qual for" (MARINONI, 2004, p. 257). 
A aplicação do art. 497 do Código de Processo Civil deve, ainda, observar o art. 536 do mesmo diploma, segundo qual estabelece, como cláusula geral executiva, a possibilidade de o juiz, de ofício ou a requerimento da parte, determinar as medidas executivas necessárias para assegurar a tutela do direito material, assim como 0 § $1^{\circ}$ do citado artigo prevê expressamente que o juiz poderá determinar o desfazimento de obras.

Em matéria urbanística, a legislação dos Municípios e do Distrito Federal estabelece regras a serem observadas, incluindo preceitos sobre usos do solo e parâmetros urbanísticos para licenciamento edilício, o que representa, por óbvio, que o direito de propriedade não é absoluto e está subordinado ao cumprimento da função social, assegurado constitucionalmente como princípio prevalecente.

O licenciamento edilício, como apresentado, deve submeter-se a procedimento administrativo próprio com a formulação do pedido pelo interessado que pretende edificar em determinado lote. O pedido deverá observar o rito do procedimento administrativo até alcançar a decisão da Administração Pública de deferimento, desde que devidamente preenchidos os requisitos legais.

A tutela de inibição de ilícito pode, ainda, ser utilizada em desfavor da Administração Pública, havendo justificado receio de que ato inválido venha a ser editado assim como para o impedimento de repetição do ilícito ou de sua continuação. Da mesma forma, a tutela de remoção de ilícito poderá servir para correção de um ato administrativo inválido, em que se objetivará a edição do ato corretor (MARTINS, 2008).

Independentemente da ocorrência de dano urbanístico ou ao meio ambiente, há situações concretas em que o interessado inicia as obras à revelia da Administração Pública sem qualquer pedido de licenciamento edilício ou com o pedido ainda em fase de análise. E, mais caótico ainda, são as situações de invasões e edificações em áreas públicas, ou mesmo particulares, não passíveis de regularização, em que os indivíduos utilizam indevidamente áreas em que não são permitidas construções, pretendendo ser beneficiados pela notória ineficiência da Administração Pública em 
fiscalizar, seja pelo tempo em que eventualmente utilizarão o imóvel sem qualquer contraprestação ou por acreditar que as ocupações se tornarão consolidadas em situações de difícil reversibilidade ou até mesmo irreversíveis. Marinoni (2019), sobre ato praticado em desacordo com a legislação urbanística ensina que

A decisão que determina a demolição, em caso de construção realizada em desacordo com a legislação urbanística, já foi qualificada de tutela ressarcitória na forma específica ou de tutela reparatória in natura na Itália e de tutela cautelar no Brasil, em conformidade com o próprio art. 888, VIII, do CPC/1973. Na raiz dos equívocos das doutrinas italiana e brasileira está a confusão entre os conceitos de ilícito e dano. Ora, a construção que desrespeita a legislação urbanística é, simplesmente, uma conduta contra ius, de modo que a determinação de demolição, nesta hipótese, não objetiva ressarcir o dano sofrido em virtude da construção irregular nem tutelar contra a probabilidade do dano, mas simplesmente remover o ilícito. Note-se que, se construir em desacordo com a lei é ilícito, as consequências que daí decorrem é que configuram o dano" (MARINONI, 2019, p. 23).

Mesmo nas situações em que a Administração Pública concedeu a licença edilícia, mas com vício, seja por ter dispensado equivocadamente a apresentação de estudo de impacto ambiental, estudo de impacto de vizinhança, pagamento de contrapartida urbana ou qualquer outra exigência prévia ao licenciamento edilício, é possível que o licenciamento seja questionado por meio da tutela inibitória ou da tutela de remoção de ilícito. Esse é o posicionamento apresentado por Marinoni:

É interessante analisar, ainda, os casos em que a administração pública licenciou uma atividade ou obra i) ao arrepio da necessidade de estudo do impacto ambiental; ii) desconsiderando, sem fundamentação, esse estudo; ou iii) baseando -se em estudo de impacto ambiental contraditório, incompleto ou fincado em omissão ou falsa descrição de informações relevantes. Nessas hipóteses, como é óbvio, não se pode pensar que não é possível inibir a atividade ou a obra (e, nesse caso, até removê-la) apenas porque o licenciamento foi concedido. Ora, se o licenciamento pode ser questionado judicialmente em todas essas situações, não pode haver dúvida quanto à possibilidade das ações inibitória e de remoção do ilícito. Com a desconstituição do licenciamento, deve haver inibição da atividade ou da obra e, se for o caso, a obra realizada - ou parte dela - deverá ser removida. Mas, diante dessa possibilidade, é inevitável, mais uma vez, a extensão da cognição[2]. 
Diante da demonstração de irregularidade no processo do licenciamento edilício, não haverá suporte legal para início ou prosseguimento da obra, bastando a verificação da contrariedade com as normas vigentes, ou seja, deve ser absolutamente afastada qualquer discussão acerca de probabilidade de dano.

O direito fundamental à tutela jurisdicional efetiva encontra fundamento no art. 50, XXXV da Constituição Federal. Assim, com a finalidade de preservar a ordem urbanística como um direito coletivo constitucionalmente assegurado, determina que além do direito material, o direito processual deve garantir medidas efetivas a fim de coibir prática de ilícito ou a sua remoção.

Nesse sentido, diante da análise do caso concreto, as tutelas inibitórias ou de remoção de ilícito devem contar com a técnica de antecipação da tutela, pois a necessidade de se aguardar o resultado final de mérito poderá beneficiar tão somente o requerido, podendo contribuir em alguns casos para situações de difícil reversão ou irreversíveis.

\section{DA TUTELA INIBITÓRIA EM CARÁTER ANTECIPADO E DA EFETIVIDADE DO PROCESSO}

A técnica antecipatória constitui um direito assegurado ao jurisdicionado de requerer e obter, de forma antecipada, o bem da vida. Mitidiero (2019) explica que

A técnica antecipatória tem por escopo realizar a tutela do direito de maneira antecipada. $O$ direito material tem prioridade e proeminência em relação às formas de tutela jurisdicional e às técnicas processuais (MITIDIERO, 2019, p. 178).

No Código de Processo Civil de 1973 havia previsão expressa para concessão de medidas liminares, contudo, no Código de Processo Civil de 2015, o legislador, de forma acertada, deixou de prever, no dispositivo, a possibilidade de concessão de medida liminar, tendo em vista que a tutela provisória pode ser concedida em qualquer ação, desde que preenchidos os pressupostos à luz do que dispõe os artigos $294 \mathrm{e}$ 300. 
$\mathrm{Na}$ hipótese de pedido de concessão da tutela final inibitória, é possível que seja formulado o pedido de tutela antecipada a fim de impedir a violação de um direito.

A técnica antecipatória, neste caso, será de tutela inibitória antecipada. Se, por sua vez, houve a prática de ato contrário ao direito, sem a configuração de dano, o pedido de concessão da tutela final será de remoção do ilícito, podendo ser concedido da mesma forma em caráter antecipado.

Marinoni (2004) explica que "essas duas espécies de tutelas são preventivas em relação ao dano" e podem ser viabilizadas mediante a aceleração da técnica de prevenção (MARINONI, 2004, p. 201). Nas lições de Cardoso (2016),

a utilização da tutela inibitória de forma antecipada não só é permitida pelos mecanismos processuais previstos na legislação processual civil como também se mostra a mais adequada para a prevenção do ilícito, desde que sejam preenchidos os requisitos legais. A tutela antecipada é o instrumento processual que garante a efetividade da ação inibitória em sua finalidade precípua, qual seja, atuar de forma preventiva a fim de assegurar a inviolabilidade do direito (CARDOSO, 2016, p. 58).

A tutela inibitória ou de remoção de ilícito de forma antecipada deve atender os requisitos do art. 300 do Código de Processo Civil quanto à demonstração, por meio de provas, da probabilidade do direito ou o risco ao resultado útil do processo, ressalvando-se não ser necessária a alegação de perigo de dano ou a sua prova, uma vez que o dano não é o pressuposto da tutela inibitória.

A tutela antecipada é um importante instrumento que "resolve de forma adequada o grave problema da necessidade de distribuição isonômica do tempo do processo", pois os efeitos decorrentes do tempo de duração do processo judicial não podem ser suportados somente pelo autor, especialmente se houver o risco ao resultado útil do processo (MARINONI, 2019, p. 121). No mesmo sentido Mitidiero (2019), ensina que

Pela antecipação de tutela, viabiliza-se a neutralização dos males oriundos do tempo necessário para obtenção da tutela jurisdicional final. A técnica antecipatória visa a distribuir de maneira isonômica entre as partes o tempo inerente à duração fisiológica do processo (MITIDIERO, 2019, p. 153). 
A técnica antecipatória nessas hipóteses terá como fundamento a urgência, caracterizada pelo perigo na demora da prestação jurisdicional, que em muitos casos, especialmente para preservação da ordem urbanística, o perigo da espera pode acarretar o comprometimento da própria tutela ao direito material. Mitidiero (2019) ensina ainda que

O perigo na demora denota a urgência na obtenção da tutela jurisdicional. A antecipação da tutela fundada na urgência deve ser concedida na medida em que existe impossibilidade de espera, sob pena de ser colocada em risco a frutuosidade da tutela do direito. Trata-se de infrutuosidade oriunda do retardo que pode tanto consentir com a ocorrência do ato ilícito, sua continuação ou reiteração, pela ocorrência ou agravamento do dano, como com o desaparecimento dos bens que podem servir à tutela do direito (MITIDIERO, 2019, p. 157).

Segundo a metodologia apresentada pelo mesmo autor, para demonstração do perigo na demora é necessário que seja objetivo, concreto, atual e grave, devendo haver elementos de realidade que justificam a sua concessão e afastam apenas uma hipótese aleatória ou o simples temor da parte, assim como deve haver justificativa e elementos que evidenciam a sua gravidade que podem colocar em risco a frutuosidade do direito (MITIDIERO, 2019).

A apresentação de provas ou de elementos para configuração da probabilidade da prática de determinado ato contrário ao direito é fundamental para a concessão da tutela inibitória ou de remoção de ilícito em caráter antecipado, o que em alguns casos pode representar certa dificuldade em evidenciar que o ilícito que ainda não ocorreu deve acontecer em futuro próximo e deverá ser evitado.

Nos termos do art. 300, $\S 2^{2}$ do Código de Processo Civil a tutela antecipada poderá ser concedida liminarmente ou mediante justificação prévia. Caso o autor não tenha provas suficientes para demonstrar a probabilidade do seu direito, poderá requerer a justificação prévia, sendo que, nesta hipótese, o juiz poderá designar audiência para inquirir testemunhas. 
Note-se que nesta hipótese de justificação prévia, em cognição sumária o juiz deverá buscar um juízo de probabilidade para a concessão da tutela antecipada e não buscar um juízo de convencimento para definição do mérito. Segundo Cardoso (2016),

O magistrado deverá, portanto, permanecer atento e sensível a esta espécie de tutela jurisdicional, a fim de que possa se valer da fungibilidade, da proporcionalidade e do juízo de ponderação na análise dos requisitos da tutela inibitória antecipada, em cada caso concreto, procurando evitar o equívoco de se pretender fazer uma leitura dos pressupostos da inibição (que se projeta para o futuro) a partir da tutela da reparação (que se baseia no dano passado), com a cautela necessária para evitar a banalização do instituto (CARDOSO, 2016, p. $61)$.

Considerando, portanto, a prerrogativa de fungibilidade da tutela inibitória antecipada, o magistrado poderá conceder a tutela que entender mais adequada ao caso concreto sem que constitua violação ao princípio da adstrição da lide (CARDOSO, 2016).

Quanto ao disposto no art. 300, §3ำ do Código de Processo Civil que trata da impossibilidade de concessão da tutela antecipada quando houver perigo de irreversibilidade dos efeitos da decisão, contudo, é necessário ponderar à luz do caso concreto, o provável direito do autor que objetiva tutela para inibição ou remoção de um ilícito em detrimento de possível dano irreversível. Nas lições de Marinoni

Admitir que a tutela antecipatória está obstaculizada, apenas porque sua concessão pode trazer um dano irreversível ao réu, é esquecer que a própria tutela antecipatória pressupõe que o direito do autor pode ser lesado e, mais do que isso, que este direito deve ser provável (MARINONI, 2019, p. 125).

A esse respeito, não se pode deixar de considerar que se a interpretação ao ordenamento jurídico se inclinar para preservar as formas convencionais de tutela, sem considerar a necessidade da tutela imediata em caráter urgente, a tutela tardia poderá não garantir o próprio direito almejado. Como já dizia Ovídio A. Baptista da Silva, para essas hipóteses,

Então muito provavelmente a proteção que o Estado vier a conceder, neste caso, será tardia e muitas vezes inútil, pois o direito, então exposto à situação do dano iminente, ao tempo da resposta jurisdicional, já não 
mais poderá realizar-se praticamente, por haver desaparecido seu objeto (BAPTISTA DA SILVA, 1993, p. 11).

Na ponderação a ser realizada pelo magistrado à luz do caso concreto, deve-se levar em consideração outro fator inerente à demora excessiva dos processos judiciais que ainda constitui um dos problemas sérios da deficiência estrutural do Poder Judiciário que pode comprometer a própria efetividade. O processo efetivo é aquele que deve observar os princípios da segurança e da celeridade em detrimento do direito material almejado (BEDAQUE, 2006).

Da mesma forma, em observância ao princípio da proporcionalidade, o juiz "deve proceder à avaliação dos interesses em jogo e dar prevalência àquele que, segundo a ordem jurídica, ostentar maior relevo e expressão" (LOPES, 2001, p. 72).

Conforme as circunstâncias do caso concreto, a não concessão da tutela inibitória ou de remoção do ilícito em caráter antecipado poderá, como consequência, constituir violação ao princípio da justiça efetiva, na medida em que o decurso do tempo do processo poderá contribuir para que os efeitos da violação já não sejam possíveis de serem restabelecidos, seja por interferir na esfera de direitos de terceiros de boa-fé ou por representar alto grau de dificuldade, por exemplo, na demolição e na mitigação dos impactos ambientais negativos em razão dos resíduos produzidos pela construção civil e demolição da edificação. Além das hipóteses apresentadas, nos termos do art. 1.012, $\S 11^{\circ}, \mathrm{V}$, do Código de Processo Civil, a tutela inibitória ou de remoção de ilícito pode ser concedida antecipadamente na sentença, ocasião em que os efeitos começam a produzir imediatamente.

\section{DA TUTELA INIBITÓRIA NEGATIVA E DA TUTELA INIBITÓRIA POSITIVA}

A tutela inibitória poderá constituir tanto uma obrigação de fazer como também uma obrigação de não fazer, que no direito anglo-americano é classificada como prohibitory injunction e mandatory injunction, sendo a primeira destinada com conteúdo proibitivo para não fazer e a segunda para impor uma obrigação de fazer. No sistema angloamericano as duas modalidades, tanto a prohibitory injunction quanto a mandatory 
injunction podem ser concedidas de forma antecipada ou ao final do processo (MARINONI, 2019).

O art. 497 do Código de Processo Civil ao dispor que o juiz poderá determinar as providências que asseguram a obtenção de tutela pelo resultado prático equivalente, considerou a possibilidade de adequação da tutela jurisdicional para obstar a prática do ilícito, seja por meio da concessão de tutela inibitória negativa ou pela concessão de tutela inibitória positiva.

Analisando-se um exemplo específico, havendo provas de que determinado evento foi autorizado pela Administração Púbica sem restrição à poluição sonora em zona residencial, é possível que o autor da ação formule um pedido para que seja determinado pelo magistrado a limitação de duração de tempo do evento a fim de não gerar incomodidade além do razoável à vizinhança ou, ainda, o pedido poderá consistir em determinar obrigação de não fazer para deixar de produzir poluição sonora que da mesma forma gere incomodidade além do razoável à vizinhança.

\section{DA TUTELA INIBITÓRIA OU DE REMOÇÃO DE ILÍCITO E AS MEDIDAS COERCITIVAS TÍPICAS E ATÍPICAS}

Para situação fática de violação às normas urbanísticas em que há claros indícios da intenção de iniciar edificação irregular, a tutela inibitória com a imposição de multa prima facie seria suficiente para impedir a prática do ilícito.

Contudo, a imposição de multa nem sempre se mostra adequada para atingir a finalidade que se pretende, tanto para a tutela inibitória como para a tutela de remoção de ilícito.

Nas hipóteses de enquadramento para concessão de tutela antecipada, o art. 297 do Código de Processo Civil autoriza o magistrado a "determinar as medidas que considerar adequadas para a efetivação da tutela provisória". 
Nos termos do art. 536 do Código de Processo Civil, ao juiz é facultado determinar o emprego de multa ou da modalidade executiva que seja capaz de atender as necessidades do caso concreto. Marinoni (2019) explica que

A norma do art. 536 é importante não só porque a ordem, quando ligada à multa, detém uma elasticidade muito grande, o que a torna passível de adequação a uma ampla variedade de situações concretas, mas também porque a tipificação dos meios de execução por sub-rogação, colocados à escolha daquele que teve seu direito reconhecido na sentença condenatória, nunca será suficiente para a tutela das várias situações de direito substancial, especialmente daquelas que surgem em decorrência da evolução da sociedade (MARINONI, 2019, p. 184).

Considerando que o sistema processual passou a conferir, ao juiz, poderes para empregar o meio executivo mais adequado ao caso concreto, de outro lado, também deverá haver o sopesamento quanto ao direito de defesa, "baseada fundamentalmente na regra que a execução deve ser feita mediante o uso do meio executivo que cause a menor restrição possível e dependente da adequada justificativa das decisões" (MARINONI, 2019, p. 185).

Além da previsão contida no art. 536 do Código de Processo Civil, dentre os poderes, deveres e responsabilidade do juiz, o art. 139, IV do Código de Processo Civil passou a conferir ao magistrado a possibilidade de determinar "todas as medidas indutivas, coercitivas, mandamentais ou sub-rogatórias para assegurar o cumprimento de ordem judicial". Segundo Oliveira Neto (2019),

Essa regra geral prevista no art. 139, IV, do CPC, representa a regramatriz do "Poder Geral de Coerção", que pode ser definido como o poder que a lei confere ao juiz para determinar, conforme as exigências do caso concreto e visando a efetividade da tutela executiva, medidas coercitivas diversas das que são expressamente previstas na legislação processual (OLIVEIRA NETO, 2019, p. 233).

As medidas coercitivas são classificadas como medidas coercitivas típicas e atípicas, sendo típicas aquelas previstas expressamente no ordenamento e atípicas as que não estão previstas expressamente e que decorrem do Poder Geral de Coerção, nos termos do art. 139, IV do Código de Processo Civil. 
Para que sejam aplicadas medidas coercitivas atípicas é preciso que seja requerido pela parte assim como deve haver demonstração da necessidade e pertinência da medida ao caso concreto (OLIVEIRA NETO, 2019).

Dentre os requisitos, portanto, deve haver a demonstração de que determinada medida se mostra necessária para efetivação da tutela jurisdicional assim como pertinente e adequada ao caso concreto (OLIVEIRA NETO, 2019). Para Mitidiero (2019),

\begin{abstract}
A antecipação de tutela inibitória, de remoção do ilícito e, em geral, de toda e qualquer tutela que se realize mediante um fazer, não fazer, entrega ou desapossamento de determinada coisa realiza-se de forma atípica no direito brasileiro. O legislador prevê, a princípio, o emprego de multa coercitiva para efetivação da antecipação de tutela que implique adoção de um fazer ou não fazer (arts. 536 e 537, CPC) e para tutela do direito à coisa (art. 538, CPC). No entanto, é franqueada igualmente ampla gama de poderes ao juiz para tutela dos direitos, sendo possível o emprego das medidas necessárias para efetivação da antecipação da tutela (arts. 139, IV, 536 e 538, CPC). É possível inclusive sancionar a parte pela não observância de uma ordem judicial ou por embaraço à realização de preceitos judiciais (art. 138, IV, CPC) (MITIDIERO, 2019, p. 182 e 183).
\end{abstract}

No âmbito da matéria de direito urbanístico, nas hipóteses de haver indícios de possível transgressão às normas urbanísticas, mostra-se adequada a tutela inibitória, ou caso o ilícito já tenha ocorrido, de remoção do ilícito, especialmente por meio da técnica de antecipação de tutela, podendo o magistrado determinar as medidas que entender adequadas.

A multa coercitiva na maioria das vezes é eficaz, contudo, deve ser dimensionada em valor suficiente levando-se em consideração o perfil do demandado, o seu potencial econômico de resistência ao cumprimento da ordem judicial, assim como a importância social ao bem jurídico que se busca tutelar (MITIDIERO, 2019).

Com fundamento no art. 297 do Código de Processo Civil e no Poder Geral de Coerção, nos termos do art. 139, IV do Código de Processo Civil, vislumbra-se a possibilidade de o magistrado além de impor obrigação para inibir a prática de ilícito sob pena de multa, conforme a pertinência e adequação ao caso concreto, determinar 
a suspensão provisória ou definitiva da carteira profissional do arquiteto ou engenheiro responsável, dar publicidade às custas do requerido para que terceiros deixem de celebrar contratos particulares de determinado loteamento clandestino ou empreendimento não licenciado, entre outros.

Assim, diante das circunstâncias do caso concreto, caberá ao magistrado conjugar o interesse do demandante com a proporcionalidade da técnica executiva, que inclui a observância do meio mais idôneo (adequação), do meio menos gravoso (necessidade) e da justificação da importância da realização da tutela (MITIDIERO, 2019).

As técnicas processuais disponíveis possibilitam, desde que observados os critérios de proporcionalidade à luz do caso concreto, alcançar a efetividade do direito material, que em direito urbanístico estão regulados por princípios e normas que visam assegurar o bem estar social no âmbito da ocupação do espaço urbano.

O sistema processual civil brasileiro evoluiu para considerar instrumentos que assegurem a realização concreta dos direitos e não mais meramente formal para que seja possível alcançar a plena efetividade do direito material (MARINONI, 2019).

\section{CONCLUSÃO}

O direito urbanístico considerado como conjunto de princípios e normas que visam regular a ocupação do espaço urbano em prol do bem estar da coletividade, submetidos ao regime de direito público, impõe para o planejamento urbano limitações para o exercício do direito de propriedade e de construir.

Conforme tratado ao longo deste trabalho, as regras de uso e ocupação do solo e as normas edilícias definem os critérios que devem ser cumpridos para o atendimento da função social da propriedade urbana, sendo o licenciamento edilício um instrumento de controle urbanístico, que tem a finalidade de a Administração Pública atestar a observância das normas pelos seus destinatários. 
O licenciamento edilício constitui ato administrativo que visa atestar a conformidade com as normas de direito público que disciplinam o direito de construir, observadas as restrições urbanísticas e ao direito de vizinhança.

Em algumas situações fáticas, é possível identificar indícios de possível transgressão às normas urbanísticas em que interessados praticam atos preparatórios à construção de edificação, começam a construir sem o respectivo licenciamento edilício ou são concedidos com vícios em contrariedade com as exigências legais.

Tais situações configuram violação às normas urbanísticas e podem ser impedidas ou mitigadas por meio da adoção de ações judiciais como pedidos de tutela inibitória ou de remoção de ilícito.

Deve-se considerar que construções não licenciadas pelo Poder Público em alguns casos não são passíveis de regularização ou podem apresentar alto grau de dificuldade de adequação à legislação urbanística local ou, ainda, podem apresentar potencial de dano reverso ainda maior em desfavor do meio ambiente urbano sustentável, especialmente nos casos de demolição de empreendimento de médio e grande porte.

Os instrumentos de controle urbanístico visam proteger a legalidade urbanística e na maioria dos casos exigem uma atuação de controle repressivo como o embargo de obra, imposição de multa, interdições no âmbito do exercício do poder de polícia. É possível ainda, como visto, na ausência de providências por parte da Administração Pública, que haja provocação do Poder Judiciário, por meio da formulação de pedido de tutela inibitória ou de remoção de ilícito.

A tutela inibitória ou de remoção de ilícito podem contar ainda com a técnica da antecipação da tutela, desde que preenchidos os requisitos legais, especialmente os elencados nos arts. 294, 297 e 300 do Código de Processo Civil.

A respeito do que prescreve o art. $300, \S 3^{\circ}$ do Código de Processo Civil, é importante que haja ponderação por parte do magistrado ao analisar a restrição de concessão da tutela antecipada quando houver possível perigo de irreversibilidade dos efeitos da 
decisão em detrimento do provável direito do autor que objetiva tutela para inibição ou remoção de um ilícito.

A utilização da técnica de antecipação de tutela se mostra adequada para a prevenção do ilícito, especialmente para garantir a efetividade do direito material da tutela inibitória.

O magistrado, como apresentado, diante da previsão legal dos arts. 139, IV e 297 do Código de Processo Civil, pode, além de impor obrigação para inibir a prática de ilícito sob pena de multa, conforme a pertinência e adequação ao caso concreto, determinar medidas coercitivas típicas e atípicas.

Portanto, nas hipóteses de o caso concreto apresentar elementos de possível violação às normas urbanísticas ou caso o ilícito tenha ocorrido, é de fundamental importância que tais condutas sejam combatidas por medidas processuais eficazes e céleres, uma vez que, conforme apresentado, construções não licenciadas pelo Poder Público podem não se enquadrar em situações de possível licenciamento posterior, assim como podem apresentar dano reverso ainda maior em desfavor do meio ambiente urbano sustentável.

\section{REFERÊNCIAS}

BAPTISTA DA SILVA, O. A. Curso de Processo Civil - Vol. III. Porto Alegre/RS: Sérgio Antônio Fabris Editor, 1993.

BEDAQUE, J. R. dos. S. Efetividade do Processo e Técnica Processual. São Paulo: Malheiros Editores, 2006.

CARDOSO, G. de. O. S. A tutela inibitória coletiva e o direito fundamental ao meio ambiente sustentável. Coord. Luiz Manoel Gomes Júnior, Luana Pedrosa de Figueiredo Cru. 1를 ed. Rio de Janeiro: LMJ Mundo Jurídico, 2016.

FIGUEIREDO, L. V. Disciplina Urbanística da Propriedade. São Paulo: Revista dos Tribunais, 1980. 
LIRA, R. P. Elementos de Direito Urbanístico. Rio de Janeiro: Renovar, 1997.

LOPES, J. B. Tutela antecipada no processo civil brasileiro. São Paulo: Saraiva, 2001.

MALUF, P. T. Licença edilícia e plano urbanístico no direito português. In: Direito Urbanístico e Ambiental. Coordenadores: Adilson Abreu Dallari e Daniela Campos Libório Di Sarno. Belo Horizonte: Editora Fórum, 2007.

MARINONI, L. G. Tutela inibitória e tutela de remoção do ilícito. $7^{a}$ ed. São Paulo: Editora Revista dos Tribunais, 2019.

MARINONI, L. G. Técnica processual e tutela dos direitos. São Paulo: Editora Revista dos Tribunais, 2004.

MARTINS, R. M. Efeitos dos Vícios do Ato Administrativo. São Paulo: Malheiros Editores, 2008.

MEIRELLES, H. L. Direito Municipal Brasileiro. 18ª ed. São Paulo: Malheiros Editores, 2017.

MITIDIERO, D. Antecipação da tutela: da tutela cautelar à técnica antecipatória. $4^{a}$ ed., ver., atual. e ampl. São Paulo: Thomson Reuters Brasil, 2019.

OlIVEIRA NETO, O. de. O Poder Geral de Coerção. São Paulo: Revista dos Tribunais, 2019.

SILVA, J. A. Direito Urbanístico Brasileiro. $7^{7}$ ed. São Paulo: Malheiros Editores, 2012.

SUNDFELD, C. A. et. al. O Estatuto da Cidade e suas Diretrizes Gerais. In: Estatuto da Cidade. São Paulo: Malheiros Editores, 2002.

SAULE JUNIOR, N. S. et. al. Estatuto da Cidade e o Plano Diretor - Possibilidades de uma Nova Ordem Legal Urbana Justa e Democrática. Porto Alegre: Sérgio Antônio Fabris, 2002. 
SAULE JUNIOR, N. S. Novas Perspectivas do Direito Urbanístico Brasileiro. Ordenamento Constitucional da Política Urbana. Aplicação e Eficácia do Plano Diretor. Porto Alegre: Sérgio Antônio Fabris Editor, 1997.

SAULE JUNIOR, N. S. et al. Os Caminhos para o Desenvolvimento da Função Socioambiental da Propriedade Pública no Brasil. Rio de Janeiro: Forense, 2014.

\section{APÊNDICE - REFERÊNCIA DE NOTA DE RODAPÉ}

2. Consulta realizada em 18.11 .2019 às $17 \mathrm{~h} 29$ no sítio eletrônico http://www.abdpc.org.br/abdpc/artigos/Luiz\%20G\%20Marinoni\%282\%29\%20\%20formatado.pdf

Enviado: Julho, 2020.

Aprovado: Julho, 2020. 